\title{
New Strategy for Chemically Attachment of Imine Group on Multi-Walled Carbon Nanotubes Surfaces: Synthesis, Characterization and Study of DC Electrical Conductivity
}

\author{
Omar Al-Shuja'a1 ${ }^{*}$, Abeer Obeid², Yousuf El-Shekeil3, Mohamed Hashim4, Zinab Al-Washali1 \\ ${ }^{1}$ Department of Chemistry, Faculty of Applied Science, Thamar University, Thamar, Yemen \\ ${ }^{2}$ Department of Chemistry, Faculty of Science, Sana'a University, Sana'a, Yemen \\ ${ }^{3}$ Mechanical Engineering Department, College of Engineering, Taibah University, Madina, KSA \\ ${ }^{4}$ Department of Environmental Pollution and Pesticides Analysis, Faculty of Agriculture, Sana'a University, Sana'a, Yemen \\ Email: *omrshugaa@yahoo.com
}

How to cite this paper: Al-Shuja'a, O., Obeid, A., El-Shekeil, Y., Hashim, M. and Al-Washali, Z. (2017) New Strategy for Chemically Attachment of Imine Group on Multi-Walled Carbon Nanotubes Surfaces: Synthesis, Characterization and Study of DC Electrical Conductivity. Journal of Materials Science and Chemical Engineering, 5, 11-21.

https://doi.org/10.4236/msce.2017.52002

Received: December 24, 2016

Accepted: February 6, 2017

Published: February 9, 2017

Copyright (c) 2017 by authors and Scientific Research Publishing Inc. This work is licensed under the Creative Commons Attribution International License (CC BY 4.0).

http://creativecommons.org/licenses/by/4.0/

\begin{abstract}
This paper used a new approach of preparing poly-composites by covalent linkage between the MWCNT's by imine group. The Poly (Imine)/MWCNT Composite was synthesized by the solution blending method from reacted amino multi-walled carbon nanotubes $\left(\mathrm{MWCNT}-\mathrm{NH}_{2}\right)$ with Terephthalaldehyde (TPAL). The obtained poly-composite was characterized by FT-IR, UV-Vis, XRD, TEM, SEM, TGA, DSC and DC electrical conductivity. The formation of Poly (Imine)/MWCNT composite was confirmed. The DC electrical conductivity of poly-composites was within the range $2.3 \times 10^{-4}-5.3 \times$ $10^{-4} \mathrm{~S} / \mathrm{cm}$ due to the interaction between the nanotubes.
\end{abstract}

\section{Keywords}

Amino Multi-Walled Carbon Nanotubes (MWCNT-NH ${ }_{2}$ ), Polymer Nanocomposites, Functionalization, Solution Blending, Imine, Terephthalaldehyde, FTIR, SEM, TEM, XRD, UV, DSC, TGA and DC Electrical Conductivity

\section{Introduction}

Nanotechnology opens up a new perspective to shape new generations of composites structures. Nanoparticles possess unique mechanical and physical properties, which make them one of the most promising fillers to develop future compo- 
sites materials [1]. Further, nanotechnology intends to reveal the size-related effects of nanoparticles to design innovative products with novel properties and functions [2] [3] [4].

The applications to which nanotechnologies can be applied cover materials manufacturing, nano-electronics and computer technology, medicine and health, aeronautics and space exploration, environment devices and information storage, biotechnology and polymer technology [5]-[11].

CNTs can be conductors like metals or semiconductors: they can transport electrons over long distances without significant interruption that makes them more effective than copper [12] [13]. This unique combination of mechanical and electrical properties makes CNTs an ideal reinforcing agent for many materials and products including polymers [14] [15]. There are many studies in the literature about composite polymers containing carbon nanotubes either with amine functional groups [16] [17] [18] [19]. However, there are no studies performed in detail with the aim of comparing the effect of carbon nanotubes with imine functional groups on poly-composites.

In this paper, a comparative analysis between the amino multi-walled carbon nanotubes (MWCNT- $\mathrm{NH}_{2}$ ) and the Poly (Imine)/MWCNT composite was performed, using comprehensive characterization techniques such as Ultravioletvisible spectroscopy (UV-Vis), Fourier transform infrared spectroscopy (FTIR), $\mathrm{X}$-ray diffraction (XRD), Thermogravimetric analysis (TGA), differential scanning calorimetry (DSC), Transmission Electron Microscopy (TEM), scanning electron microscopy (SEM) and DC electrical conductivity. Thus, a new approach of poly-composites by covalent linkage between the MWCNT's by imine group was synthesized.

\section{Experimental}

\subsection{Materials}

Amino Multi-walled carbon nanotubes $\left(\mathrm{MWCNT}-\mathrm{NH}_{2}\right)$ were purchased from Timesnano (Chengdu Organic Chemicals Co. Ltd., Chinese Academy of Sciences) China. The diameter and length of MWCNT- $\mathrm{NH}_{2}$ ranged between $8-15 \mathrm{~nm}$ and $50 \mu \mathrm{m}$ respectively. Purity was over $>95 \%$ and the amine group coverage was over the nanotube surface of $(0.45 \mathrm{wt} \%)$. Terephthalaldehyde (TPAL), $N, N$-Dimethylformamide (DMF 99\%), and Tetrahydrofuran (THF 99.9\%) were purchased from Sigma Aldrich, and used as received without any further treatment.

\subsection{Instrumentation}

The FTIR spectra were recorded using the $\mathrm{KBr}$ disc technique on a JASCO 410 FTIR Spectrophotometer. The melting points were measured with an electrothermal melting point apparatus. The thermal analyses (TGA and DSC) were carried out on a Mettler Toledo TGA/SDTA851e analyzer, and Mettler Toledo DSC823e analyzer, respectively, at $23^{\circ} \mathrm{C}$ to $1000^{\circ} \mathrm{C}$, under $20 \mathrm{ml}$ nitrogen per minute and a heating rate of $10^{\circ} \mathrm{C}$ per minute. UV-vis absorption spectra were 
measured using a Specord 200, Analytik Jana, Germany in DMF ( $\sim 10$ - 4 $\mathrm{mol} / \mathrm{dm}^{3}$ ). The X-Ray diffraction was carried out on a BrukerAxs Da Advance, Germany. Electrical conductivity measurements were taken on a Keithley Picoammeter/Voltage Source Model 6487 using a double probe locally fabricated conductivity bridge cell. The Scanning Electron Microscope (SEM) was carried out on a (SEM HITACHI S-3400N) instrument. The Transmission Electron Microscope (TEM) was carried out on a Phillips CM-12, USA; and the samples were prepared by Leica ultracut UTC ultramicrotome (JEOL, Japan) with an accelerating voltage of $100 \mathrm{kV}$.

\subsection{Preparation of Poly (Imine)/MWCNT Composites}

$0.3 \mathrm{~g}$ sample of MWCNT- $\mathrm{NH}_{2}$ was dispersed in $15 \mathrm{ml}$ THF and $0.1 \mathrm{~g}$ of TPAL was dissolved in $10 \mathrm{ml} \mathrm{DMF}$ and was added to the MWCNT- $\mathrm{NH}_{2}$ dispersion in THF. The mixture was then stirred for 24 hours at $90^{\circ} \mathrm{C}$ under reflux. After cooling to room temperature, the mixture was vacuum-filtered through a 0.22 $\mu \mathrm{m}$ membrane and was thoroughly washed several times with THF. The filtered solid was then dried overnight in a vacuum oven at $90^{\circ} \mathrm{C}$ [20] [21].

\section{Results and Discussion}

\subsection{Characterization}

Poly (Imine)/MWCNT composite was prepared by the reaction of MWCNT-NH with TPAL in refluxing solvent (DMF) to yield poly-composites products. The method employed to prepare the Poly (Imine)/MWCNT composite was solution blending. The scheme of synthesis of the Poly (Imine)/MWCNT composite is shown in Figure 1. The physical properties were studied of $\mathrm{MWCNT}-\mathrm{NH}_{2}$ and Poly (Imine)/MWCNT composite. The melting point $>350^{\circ} \mathrm{C}$ and the color were black for both compounds, and the percentage yield was $87 \%$. The solubility for MWCNT- $\mathrm{NH}_{2}$ and Poly (Imine)/MWCNT composite was also studied, showing good solubility mainly in Dimethyl sulfoxide (DMSO) and partially soluble in Dimethyl formamide (DMF) and ethanol 99.99\% (EtOH).

\subsection{Fourier Transform Infrared Spectroscopy (FTIR)}

In Figure 2, the IR spectra of MWCNT- $\mathrm{NH}_{2}$ show the peak at $3448 \mathrm{~cm}^{-1}$, which can be assigned to the $\mathrm{NH}_{2}$ stretch of the amine group. While $\mathrm{C}-\mathrm{N}$ bond stretch vibrations appear at $1050 \mathrm{~cm}^{-1}$, the peaks at $1578-1654 \mathrm{~cm}^{-1}$ can be associated

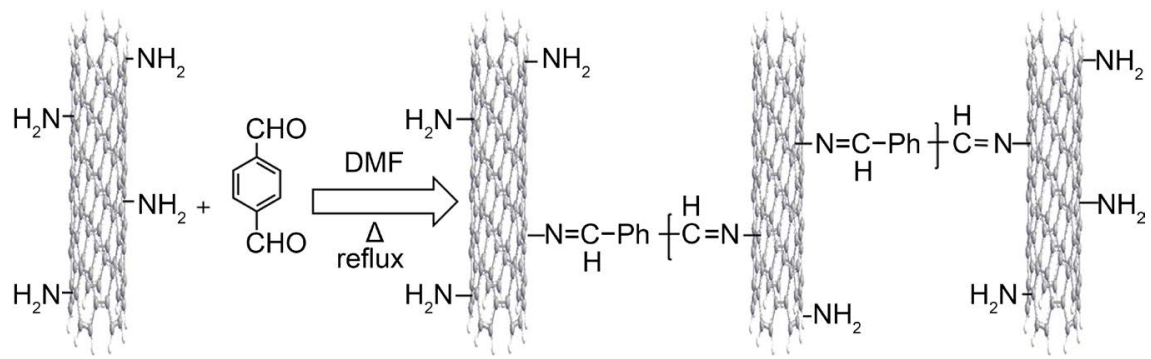

Figure 1. Synthesis of Poly (Imine)/MWCNT composite. 


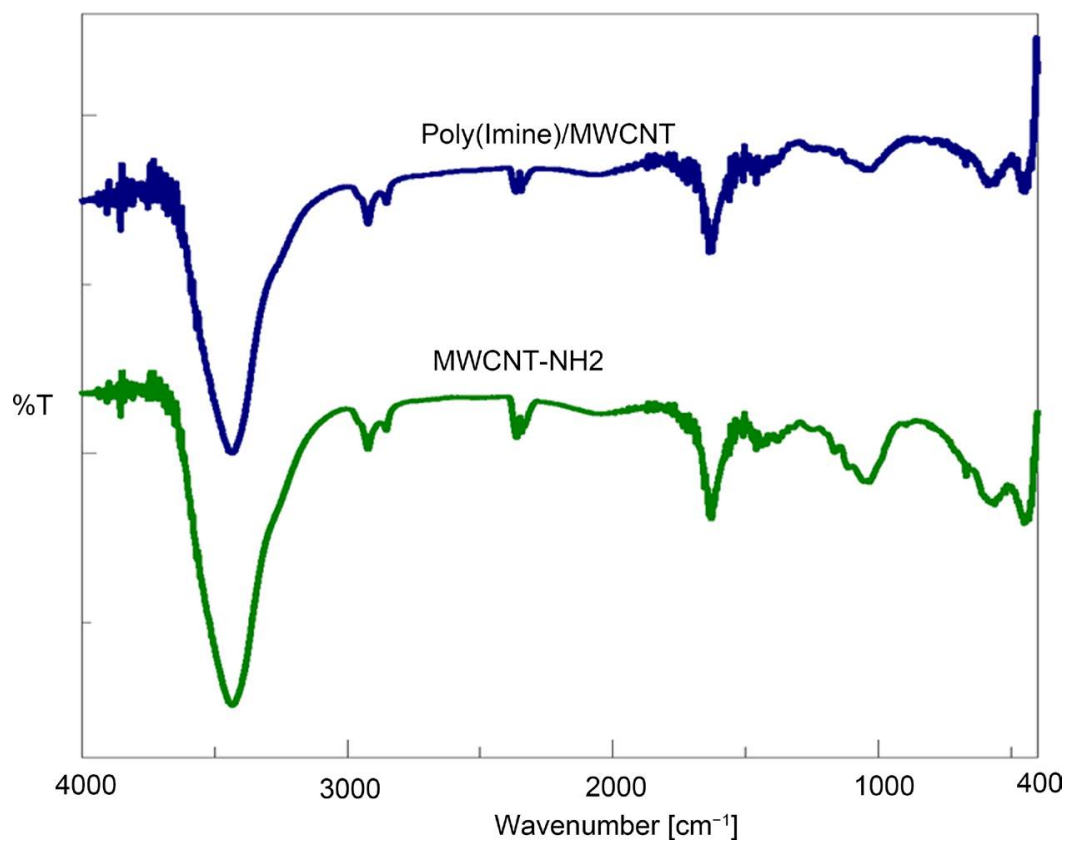

Figure 2. FTIR spectra of MWCNT- $\mathrm{NH}_{2}$ and Poly (Imine)/MWCNT composite.

with the $\mathrm{C}=\mathrm{C}$ stretching vibration of the MWCNT backbone [19].

Figure 2 shows the IR spectrum of the Poly (Imine)/MWCNT composite; and the bands around $1637 \mathrm{~cm}^{-1}$ correspond to the stretching vibration of the $\mathrm{C}=\mathrm{N}$ group of the imine and $\mathrm{C}=\mathrm{C}$ backbone [22]. The broad peak at $3433 \mathrm{~cm}^{-1}$, which can be assigned to the N-H stretch from amine group, suggests that not all the amine group has been converted to imine. We can say that there is still a small amount of unreacted amine group. The peaks of aldehyde do not appear like $\mathrm{C}=\mathrm{O}$ at $1725 \mathrm{~cm}^{-1}$ and $\mathrm{C}-\mathrm{H}$ stretch at $2750 \mathrm{~cm}^{-1}$.

\subsection{UV/Vis Spectroscopy}

UV-visible absorptions of MWCNT- $\mathrm{NH}_{2}$ and Poly (Imine)/MWCNT are illustrated in Figure 3. MWCNT- $\mathrm{NH}_{2}$ shows one $\pi-\pi^{\star}$ transition $\lambda_{\max }$ at $280 \mathrm{~nm}$ and $\mathrm{n}-\pi^{*}$ transition at $\lambda_{\max }$ at $324 \mathrm{~nm}$. However, the spectra of the Poly (Imine)/MWCNT show absorption with a lower shift of $\pi-\pi^{*}$ transition $\lambda_{\max }$ at 278 $\mathrm{nm}$. $\mathrm{n}-\pi^{*}$ transition at $\lambda_{\max }$ shows the shift at $318 \mathrm{~nm}$. This confirms the imine formation.

\subsection{Microscopy Characterization (TEM, SEM)}

\subsubsection{Transmission Electron Microscopy (TEM)}

Figures 4(a)-(d) display TEM microphotographs of the MWCNT-NH $\mathrm{N}_{2}$ and Poly (Imine)/MWCNT composite at different magnifications. Figure 4(a) \& Figure 4(b) show TEM images of MWCNT-NH$H_{2}$; it can be noticed that MWCNT- $\mathrm{NH}_{2}$ compounds appear low-entangled with an average diameter of $8-15 \mathrm{~nm}$ and their average length is approximately equal to $50 \mu \mathrm{m}$ as announced by the supplier (Timesnano). A spot shape is observed, which may be attributed to $\mathrm{NH}_{2}$ groups. 


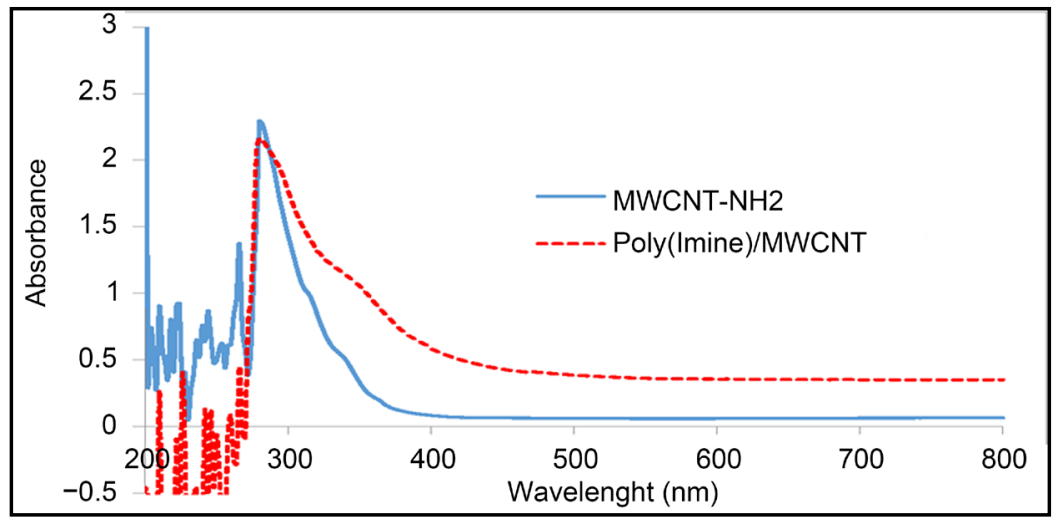

Figure 3. UV-vis spectra of MWCNT-NH $\mathrm{N}_{2}$ and Poly (Imine)/MWCNT composite.
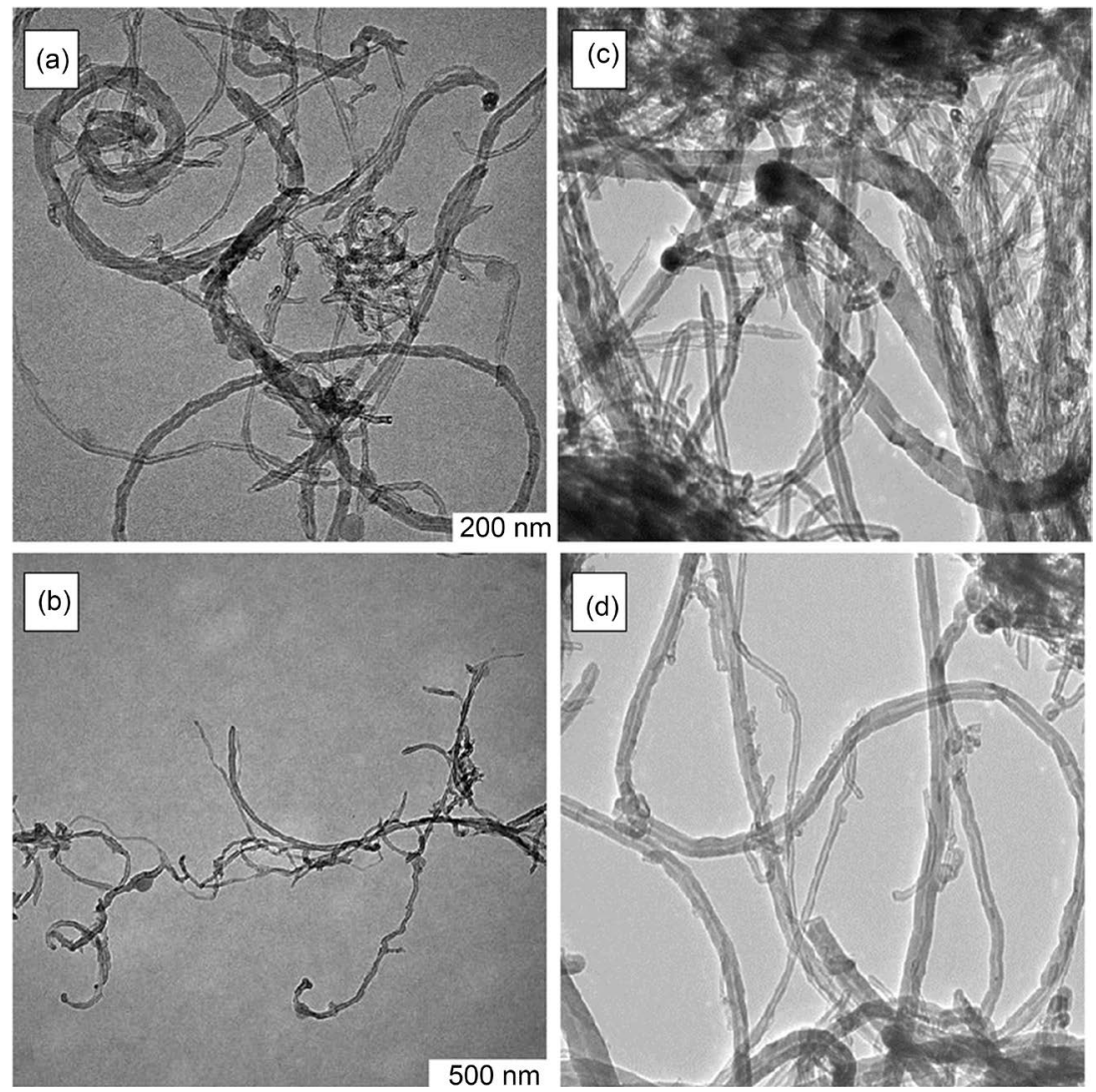

Figure 4. TEM microphotograph of MWCNT- $\mathrm{NH}_{2}$ and Poly (Imine)/MWCNT composite: MWCNT-NH $\mathrm{NH}_{2}$ (a) $\times 50,000$; (b) $\times 100,000$ and Poly (Imine)/MWCNT (c) low magnification; (d) high magnification.

As shown in Figure 4(c) \& Figure 4(d), the TEM of Poly (Imine)/MWCNT composite is the relatively good dispersion and more entangled than the pristine MWCNT- $\mathrm{NH}_{2}$. In addition, the spot shape disappeared, which may be referred to the formed imine bonds, which make a tight crossed link between the nanotubes.

\subsubsection{Scanning Electron Microscopy (SEM)}

Figures 5(a)-(h) show SEM microphotographs of the surface morphology and 


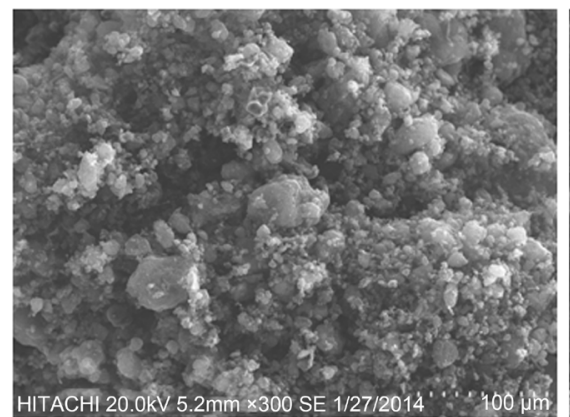

(a)

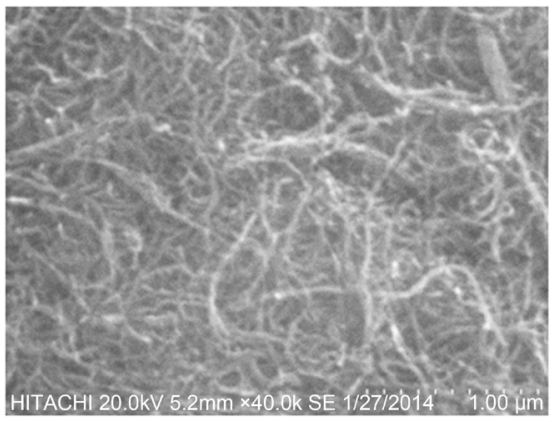

(d)

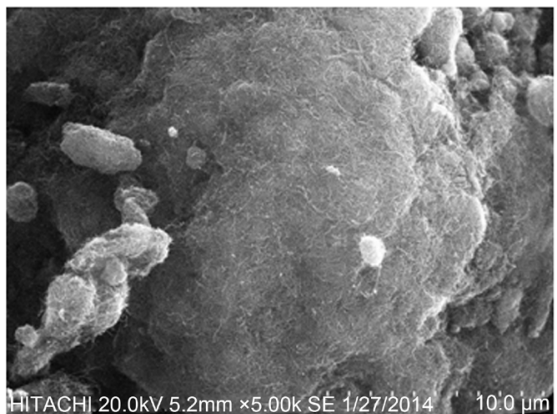

(b)

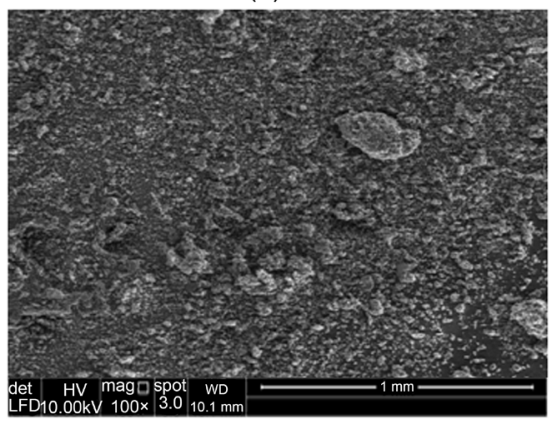

(e)

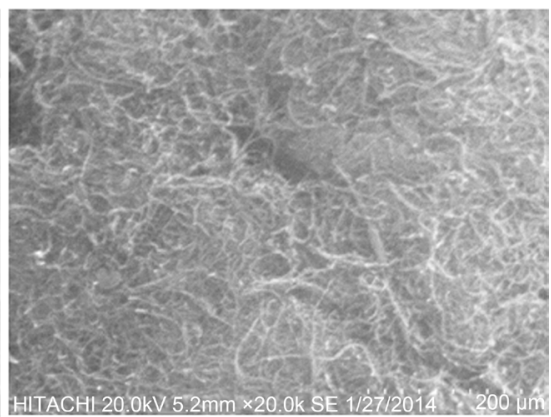

(c)

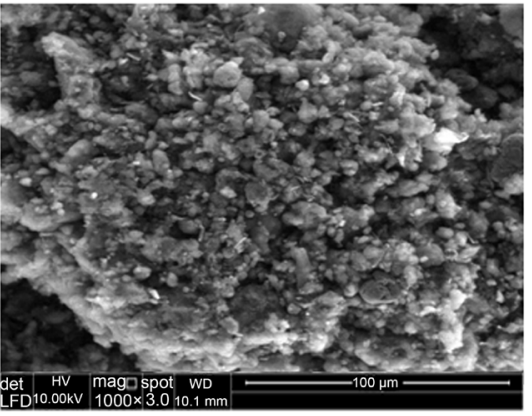

(f)

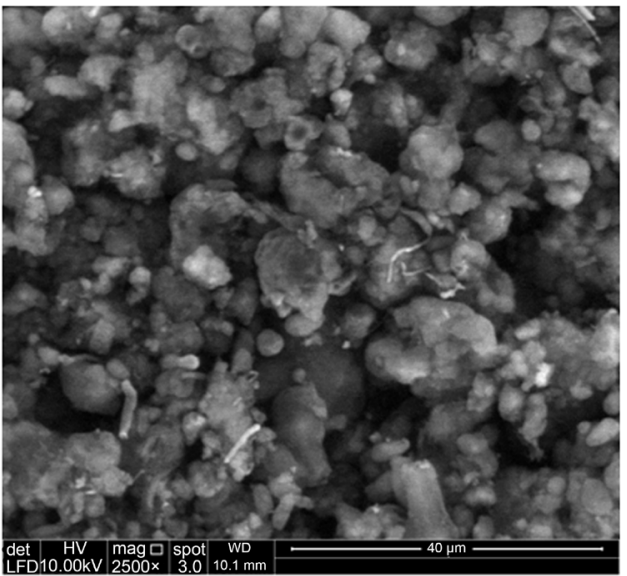

(g)

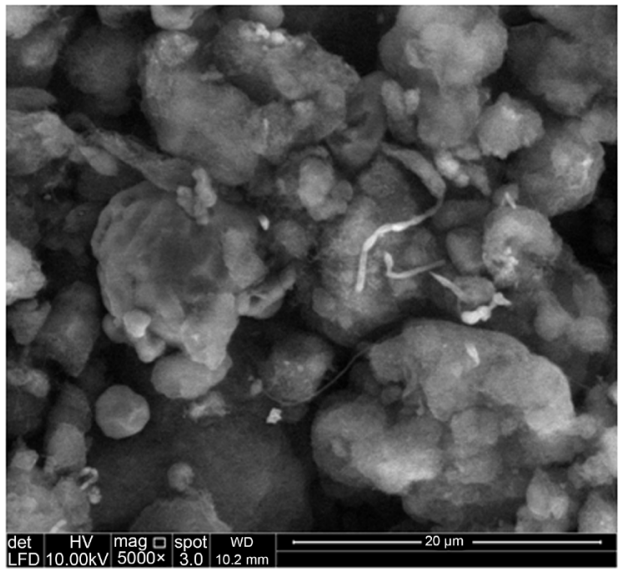

(h)

Figure 5. SEM microphotograph of MWCNT- $\mathrm{NH}_{2}$ and Poly (Imine)/MWCNTcomposite: (a) $\mathrm{MWCNT}^{-\mathrm{NH}_{2}}(\times 300)$, (b) MWCNT-NH $\mathrm{NH}_{2}(\times 5000)$, (c) MWCNT-NH $(\times 20,000)$, (d) MWCNT-NH $\mathrm{NH}_{2}(\times 40,000)$, (e) Poly (Imine)/MWCNT (×100), (f) Poly (Imine)/MWCNT (×1000), (g) Poly (Imine)/MWCNT (×2500), (h) Poly (Imine)/MWCNT (×5000).

dispersion of the MWCNT- $\mathrm{NH}_{2}$ and Poly (Imine)/MWCNT composite at different magnifications. An agglomeration of MWCNT- $\mathrm{NH}_{2}$ larger than Poly (Imine)/MWCNT was observed. The images clearly show that the surface morphology of Poly (Imine)/MWCNT composite is significantly different, compared to MWCNT- $\mathrm{NH}_{2}$.

\subsection{X-Ray Diffraction}

Figure 6 exhibits the XRD pattern of MWNT- $\mathrm{NH}_{2}$ and Poly (Imine)/MWCNT composite. XRD patterns show that the crystallinity of composite is higher than that of MWNT- $\mathrm{NH}_{2}$. The diffraction patterns, having large diffraction peaks resulting from the nanoscale, suggest enhanced crystallinity. The sharp and strong 
diffraction peak of MWCNT- $\mathrm{NH}_{2}$ at $2 \theta=26.6^{\circ}$ correspond to the hexagonal graphite structure support [23] in Figure 6(a). In Figure 6(b), it appears that the intensity of the diffraction peak of Poly (Imine)/MWCNT is sharper than that of the MWCNT- $\mathrm{NH}_{2}$. This behavior may indicate that the crystallinity of Poly (Imine)/MWCNT is higher than MWCNT- $\mathrm{NH}_{2}$ which may be due to covalent linkage between the MWCNT's by organic compound (Imine group) with less angle strain. That constitutes the evidence for the fact that the treatment was safe and enhanced the graphene layer organization [18] [24].

\subsection{Thermal Properties (Thermogravimetric Analysis (TGA) and Differential Scanning Calorimetry [DSC])}

The TGA (TG and DTG) and DSC curves recorded for the MWCNT-NH $\mathrm{N}_{2}$ and Poly (Imine)/MWCNT composite are given in Figure 7 and Figure 8, and summarized in Table 1 . The high thermal stability of MWCNT- $\mathrm{NH}_{2}$, which is related to the surface of nanotubes defects with very little amount of $-\mathrm{NH}_{2}$ group $(0.45 \%)$, has a similar behavior of MWCNT [25]. The degradation process of $\mathrm{MWNT}^{-\mathrm{NH}_{2}}$ does not exhibit any step until $600^{\circ} \mathrm{C}$, which confirms the MWNT- $\mathrm{NH}_{2}$ thermally stable [19].

The degradation process of Poly (Imine)/MWCNT composite exhibits two

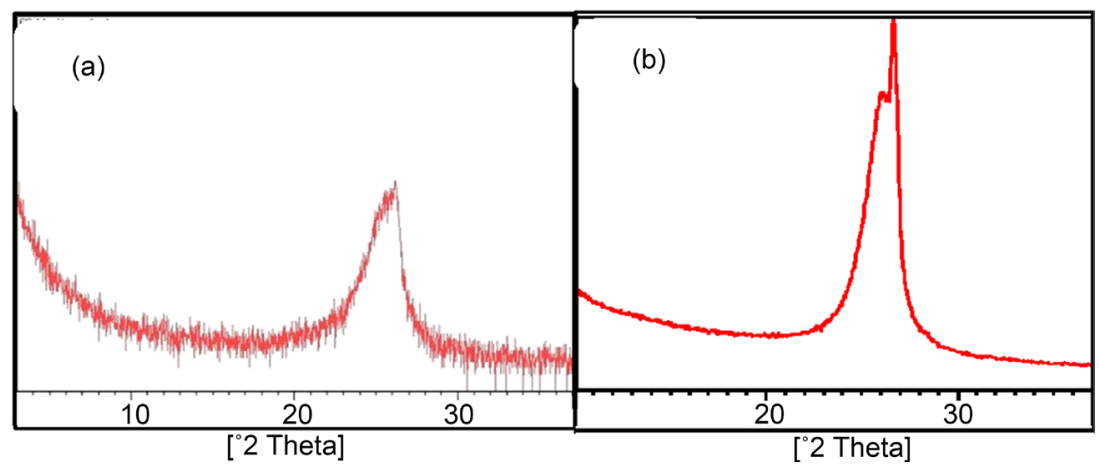

Figure 6. X-ray diffraction of (a) MWCNT-NH $\mathrm{H}_{2}$ and (b) Poly (Imine)/MWCNT composite.

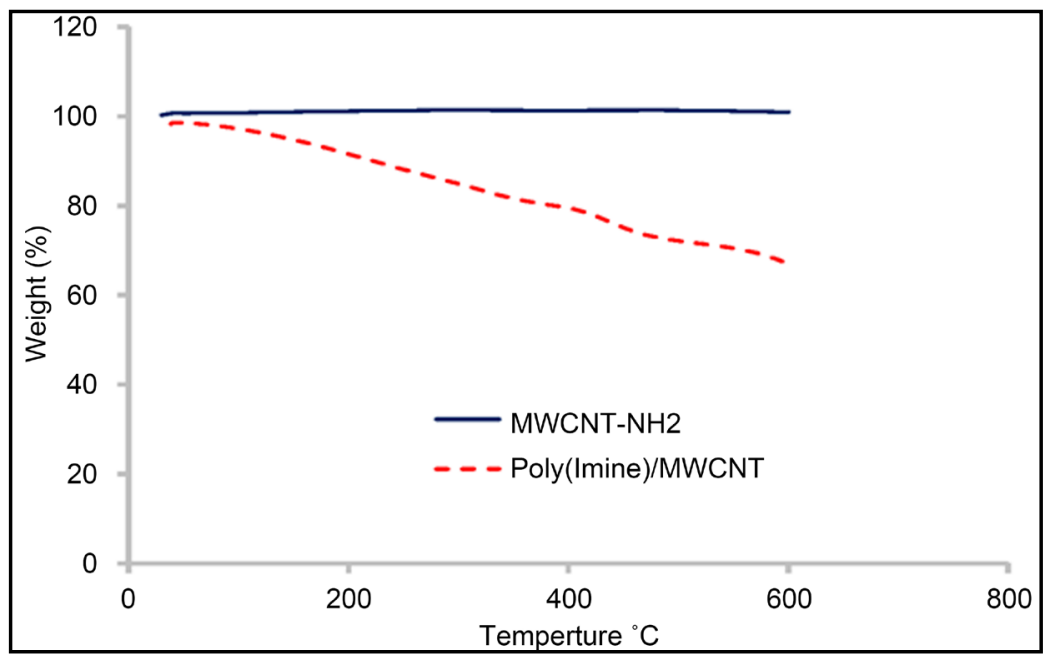

Figure 7. TGA curves of MWCNT- $\mathrm{NH}_{2}$ and Poly (Imine)/MWCNT composite. 


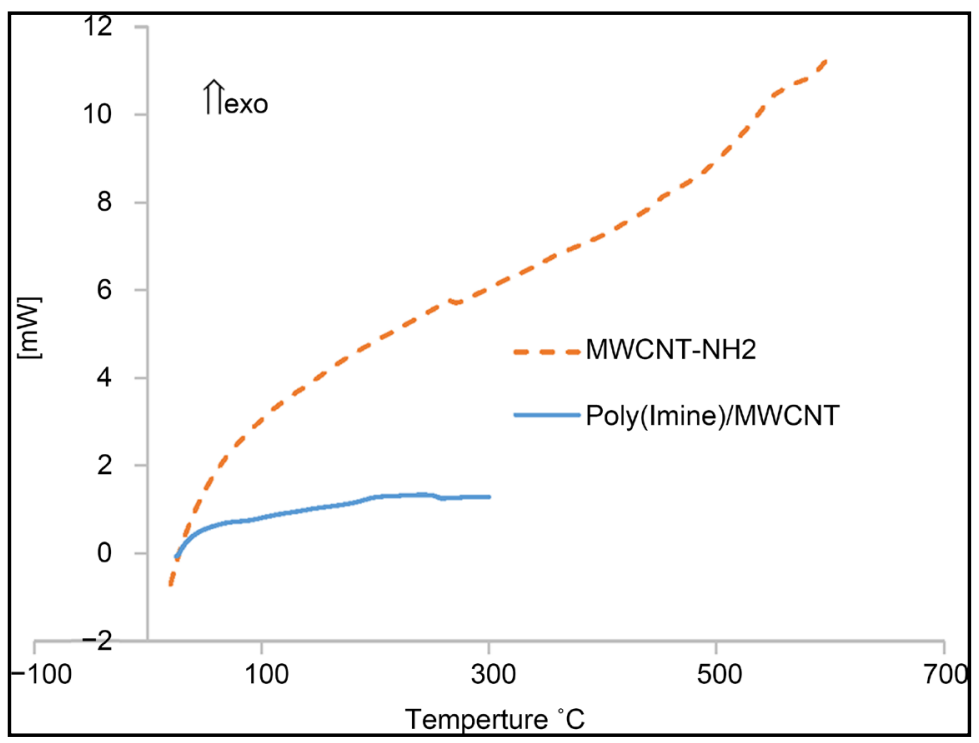

Figure 8. DSC curves of MWCNT- $\mathrm{NH}_{2}$ and Poly (Imine)/MWCNT composite.

Table 1. TGA and DSC results of MWCNT- $\mathrm{NH}_{2}$ and Poly (Imine)/MWCNT composite.

\begin{tabular}{ccccccccc}
\hline & & \multicolumn{3}{c}{ TGA } & \multicolumn{3}{c}{ DSC } & \multirow{2}{*}{ Compound } \\
\cline { 3 - 7 } & Step. \% & $\begin{array}{c}\text { Wt. } \\
\text { Loss } \%\end{array}$ & $T_{\mathrm{i}} /{ }^{\circ} \mathrm{C}$ & $T_{\mathrm{f}} /{ }^{\circ} \mathrm{C}$ & $T_{\mathrm{DTG}}$ & $T_{\mathrm{DCS}}$ & Peak & \\
\hline MWCNT-NH 2 & $1^{\text {st }}$ & 0.0 & - & - & - & - & - & 100 \\
& $1^{\text {st }}$ & 16.9 & 74.6 & 359.6 & 90.86 & endo & 81.1 \\
Poly (Imine)/MWCNT & $2^{\text {nd }}$ & 9 & 359.9 & 500.8 & - & - & 72.1 \\
& $3^{\text {rd }}$ & 5.1 & 500.8 & 600 & - & - & 67.0 \\
\hline
\end{tabular}

Endo: endothermic peak; $T_{\mathrm{i}}$ : Initial point temperature of decomposition; $T_{\mathrm{f}}$ : Final point temperature of decomposition; $T_{\mathrm{DTG}}$ : temperature of maximum rate of weight loss of the DTG curve; $T_{\mathrm{DSC}}$ : temperature of maximum rate of weight loss of the DSC curve.

steps: the first one at $\left(75^{\circ} \mathrm{C}-359^{\circ} \mathrm{C}\right)$ probably assigned to the broken imine groups and the $2^{\text {nd }}$ and $3^{\text {rd }}$ steps at $(359-500)$ and $\left(500^{\circ} \mathrm{C}-600^{\circ} \mathrm{C}\right)$, respectively, are normally attributed to organic backbone structures degradation.

\subsection{Electrical Conductivity}

It is generally agreed that the mechanism of conductivity in the $\pi$-conjugated polymeric materials is based on the motion of charge defects within the conjugated framework. The charge carriers, either positive p-type or negative n-type, are the products of oxidizing or reducing the material, respectively. The following overview describes these processes in the context of p-type carriers although the concepts are equally applicable to n-type carriers [26] [27].

Figure 9 shows DC electrical conductivity of MWCNT- $\mathrm{NH}_{2}$ and Poly (Imine)/MWCNT composite at room temperature. The order of DC electrical con-

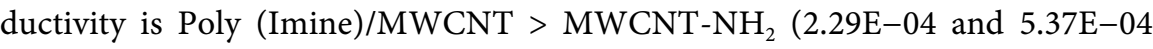
$\mathrm{S} / \mathrm{cm}$ ), respectively. There is a slight increase of the DC electrical conductivity of Poly (Imine)/MWCNT that may be attributed to less co-planarity according to 


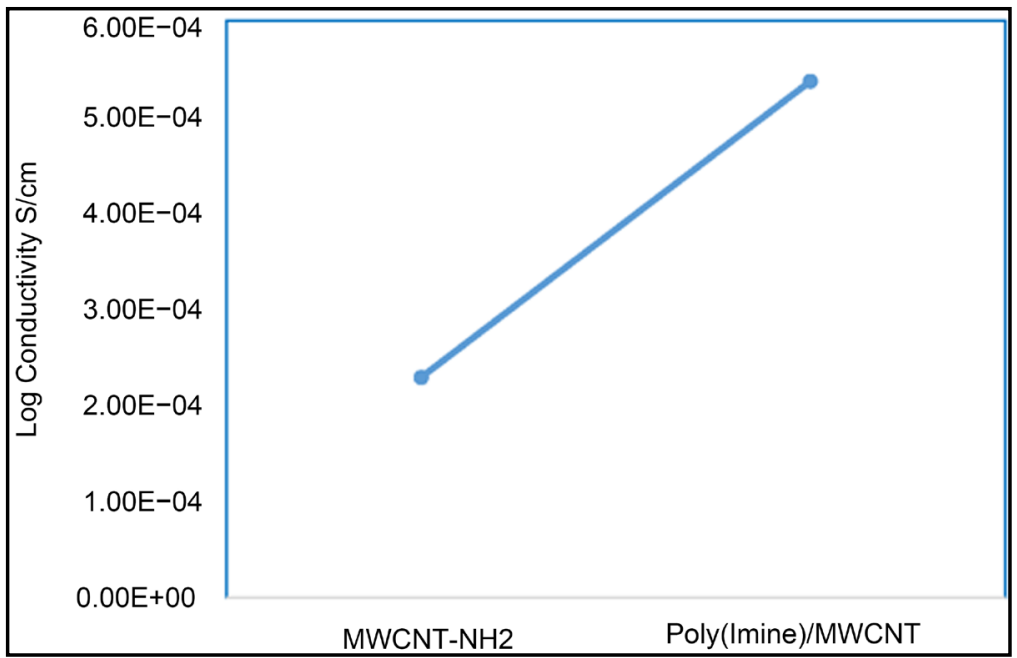

Figure 9. Shows DC electrical conductivity of MWCNT- $\mathrm{NH}_{2}$ and Poly (Imine)/MWCNT composite at room temperature.

random distribution of the amino group in the surface of MWCNT [28] [29]. The results further show that the functionalization of carbon nanotubes with different functional groups has insignificant effect on conductivity [18] [30].

\section{Conclusion}

In conclusion, the method employed to prepare the Poly (Imine)/MWCNT composite was solution blending by the reaction of MWCNT- $\mathrm{NH}_{2}$ with Terephthalaldehyde (TPAL). The obtained poly-composite was characterized by FT-IR, UV-Vis, XRD, TEM, SEM, TGA, DSC and DC electrical conductivity. $\mathrm{X}$-ray diffraction shows that the crystallinity of composite is higher than of MWNT- $\mathrm{NH}_{2}$; and the highest thermal stability of MWCNT- $\mathrm{NH}_{2}$ is related to the hydrogen bond. Further, the thermal stability of Poly (Imine)/MWCNT connected to conjugation of aromatic ring. There is a slight increase of the DC electrical conductivity of Poly (Imine)/MWCNT, which may be attributed to less co-planarity according to random distribution of amino group in the surface of MWCNT. The results show that the functionalization of carbon nanotubes with imine functional groups has insignificant effects on conductivity.

\section{Acknowledgements}

The authors would like to express their gratitude and thanks to Prof. Ali ElShekeil, Professor of Organic Chemistry, Faculty of Science, Sana'a University, Yemen, and his group (Polymers Group) for the great efforts they have made, and for their scholarly cooperation by allowing us to use their instrument to perform the DC electrical conductivity measurements.

\section{References}

[1] Harris, P.J.F. (1999) Carbon Nanotubes and Related Structures. Cambridge University Press, Cambridge, 16-24. https://doi.org/10.1017/cbo9780511605819

[2] Ajayan, P.M., Charlier, J.C. and Rinzler, A.G. (1999) Carbon Nanotubes: From Ma- 
cromolecules to Nanotechnology. Proceeding of the National Academy of Sciences of the United States of America, 96, 14199-14200.

https://doi.org/10.1073/pnas.96.25.14199

[3] Ratner, M. and Ratner, D. (2003) Nanotechnology: A Gentle Introduction to the Next Big Idea. Upper Saddle River, Prentice Hall.

[4] Taniguchi, N. (1974) On the Basic Concept of Nanotechnology. Proceedings of the International Conference on Production Engineering, Tokyo, 18-23.

[5] Biercuk, M.J., Llaguno, M.C., Radosavljevic, M., Hyun, J.K., Johnson, A.T. and Fischer, J.E. (2002) Carbon Nanotube Composites for Thermal Management. Applied Physics Letters, 80, 2767-2769. https://doi.org/10.1063/1.1469696

[6] Krishnamoorti, R. and Vaia, R. (2002) Polymer Nanocomposites: Introduction. In: Krishnamoorti, R. and Vaia, R., Eds., Polymer Nanocomposites-Synthesis, Characterization and Modeling, ACS Symposium Series, Vol. 804, American Chemical Society, Washington, DC.

[7] Santhanam, V. and Andres, R.P. (2004) Metal Nanoparticles and Self-Assembly into Electronic Nanostructures. In: Schwarz, J.A., Contescu, C.I. and Putyera, K., Eds., Dekker Encyclopedia of Nanoscience and Nanotechnology, CRC Press, Boca Raton, 4014.

[8] Kroto, H.W., Heath, J.R., O’Brien, S.C., Curl, R.F. and Smalley, R.E. (1985) C60: Buckminsterfullerene. Nature, 318, 162-163. https://doi.org/10.1038/318162a0

[9] Meyyappan, M. (2005) Carbon Nanotubes: Science and Applications. CRC Press, Boca Raton, 28.

[10] Ajayan, P.M., Stephan, O., Colliex, C. and Trauth, D. (1994) Aligned Carbon Nanotube Arrays Formed by Cutting a Polymer Resin-Nanotube Composite. Science, 265, 1212-1214. https://doi.org/10.1126/science.265.5176.1212

[11] Dresselhaus, M.S., Dresselhaus, G. and Eklund, P.C. (1996) Science of Fullerenes and Carbon Nanotubes. 2nd Edition, Springer, New York, 922.

[12] Wei, B.Q., Vajtai, R. and Ajayan P.M. (2001) Reliability and Current Carrying Capacity of Carbon Nanotubes. Applied Physics Letters, 79, 1172-1174. https://doi.org/10.1063/1.1396632

[13] Durkop, T., Kim, B.M. and Fuhrer, M.S. (2004) Properties and Applications of High-Mobility Semiconducting Nanotubes. Journal of Physics: Condensed Matter, 16, 553-580. https://doi.org/10.1088/0953-8984/16/18/r01

[14] Bardash, L. (2011) Synthesis and Investigation of Nanostructured Polymer Composites Based on Heterocyclic Esters and Carbon Nanotubes. Other Universite Claude Bernard, Lyon.

[15] Breuer, O. and Sundararaj, U. (2004) Big Returns from Small Fibers: A Review of Polymer/Carbon Nanotube Composites. Polymer Composites, 25, 630-645. https://doi.org/10.1002/pc.20058

[16] Atieh, M.A. (2011) Effect of Functionalize Carbon Nanotubes with Amine Functional Group on the Mechanical and Thermal Properties of Styrene Butadiene Rubber. Journal of Thermoplastic Composite Materials, 24, 613-624. https://doi.org/10.1177/0892705710397456

[17] Saeed, K. and Park, S.Y. (2010) Preparation and Characterization of Multiwalled Carbon Nanotubes/Polyacrylonitrile Nanofibers. Journal Polymer Research, 17, 535-540. https://doi.org/10.1007/s10965-009-9341-4

[18] Yuen, S.M., Ma, C.C., Lin, Y.Y. and Kuan, H.C. (2007) Preparation, Morphology and Properties of Acid and Amine Modified Multiwalled Carbon Nanotube/Polyimide Composite. Composites Science and Technology, 67, 2564-2573. 
https://doi.org/10.1016/j.compscitech.2006.12.006

[19] Eren, O., Ucar, N., Onen, A., Karacan, I., Kızıldag, N., Demirsoy, N., Vurur, O.F. and Borazan, I. (2016) Effect of Differently Functionalized Carbon Nanotubes on the Properties of Composite Nanofibres. Indian Journal of Fibre \& Textile Research, 41, 138-144.

[20] Li, Z., Li, S., Yang, M. and Huang, R. (2005) A Novel Approach to Preparing Carbon Nanotube Reinforced Thermoplastic Polymer Composites. Carbon, 43, 2413 2416. https://doi.org/10.1016/j.carbon.2005.04.037

[21] Moniruzzaman, M. and Winey, K.I. (2006) Polymer Nanocomposites Containing Carbon Nanotubes. Macromolecules, 39, 5194-5205. https://doi.org/10.1021/ma060733p

[22] Moradi, L., Bina, M.R. and Partovi, T. (2014) New Strategy for Chemically Attachment of Schiff Base Complexes on Multiwalled Carbon Nanotubes Surfaces. Cur rent Chemistry Letters, 3, 147-156. https://doi.org/10.5267/j.ccl.2014.5.004

[23] Sagar, S., Iqbal, N. and Maqsood, A. (2013) Dielectric, Electric and Thermal Properties of Carboxylic Functionalized Multiwalled Carbon Nanotubes Impregnated Polydimethylsiloxane Nanocomposite. Journal of Physics. Conference Series, 439, Article ID: 012024.

[24] Suh, J.Y., Shin, S.E. and Bae, D.H. (2016) Electrical Properties of Polytetrafluoroethylene/Few-Layer Graphene Composites Fabricated by Solid-State Processing. Journal of Composite Materials, Online. https://doi.org/10.1177/0021998316674349

[25] Zenkel, C., Albuerne, J., Emmler, T., Boschetti-de-Fierro, A., Helbig, J. and Abetz, V. (2012) New Strategies for the Chemical Characterization of Multi-Walled Carbon Nanotubes and Their Derivatives. Microchimica Acta, 179, 41-48. https://doi.org/10.1007/s00604-012-0848-8

[26] Al-Yusufy, F., El-Shekeil, A., Al-Shuja'a, O. and Qataei, M. (2014) Syntheses, Characterization and DC Electrical Conductivity of Phenylene Imidazole Phenanthroline Dendritic and Linear Metal Complexes: A Comparative Study. Journal of Macromolecular Science Part A: Pure and Applied Chemistry, 51, 689-698. https://doi.org/10.1080/10601325.2014.936233

[27] El-Shekeil, A., Al-Yusufy, F., Al-Shuja'a, O. and Qataei, M. (2015) DC Electrical Conductivity of Three-Branched Dendritic and Linear Metal Complexes of N-Substituted Imidazole Phenanthroline Derivatives. Journal of Macromolecular Science Part A: Pure and Applied Chemistry, 52, 809-820. https://doi.org/10.1080/10601325.2015.1067038

[28] Al-Shuja'a, O., Obeid, A. and El-Shekeil, A. (2011) Spectral, Thermal and DC Electrical Conductivity of Charge Transfer Complex Formed between 5,7-Dimethyl-1Oxo-2-Phenyl-1H-Pyrazolo [1,2- $\alpha$ ]Pyrazol-4-ium-3-Olate and Iodine. Journal of Macromolecular Science Part A: Pure and Applied Chemistry, 48, 355-364. https://doi.org/10.1080/10601325.2011.562465

[29] Obeid, A., Al-Shuja'a, O., Aqeel, S., Al-Aghbari, S. and El-Shekeil, A. (2012) DC Electrical Conductivity of Some Oligoazomethines Doped with Nanotubes. Journal of Macromolecular Science Part A: Pure and Applied Chemistry, 49, 116-123. https://doi.org/10.1080/10601325.2012.641906

[30] Aqeel, S., Al-Shuja'a, O., Huang, Z., Le, C., Zhang, Y. and Wang, Z. (2015) Improved Thermal and Electrical Properties of Nanocomposites Based on Poly(Vinyl pyrrolidone)/Poly(Acrylonitrile)/Multiwalled Carbon Nanotubes. Journal of Chemical Engineering and Chemistry Research, 2, 771-779. 
Submit or recommend next manuscript to SCIRP and we will provide best service for you:

Accepting pre-submission inquiries through Email, Facebook, LinkedIn, Twitter, etc. A wide selection of journals (inclusive of 9 subjects, more than 200 journals)

Providing 24-hour high-quality service

User-friendly online submission system

Fair and swift peer-review system

Efficient typesetting and proofreading procedure

Display of the result of downloads and visits, as well as the number of cited articles Maximum dissemination of your research work

Submit your manuscript at: http://papersubmission.scirp.org/

Or contact msce@scirp.org 